\title{
THE DIVERGENCE OF THE KNOWLEDGE AND THE VALUE SYSTEM OF GIRIKERTO VILLAGERS OF TURI SUBDISTRICT OF SLEMAN
}

\author{
Yusdani dan Imam Samroni \\ Pusat Studi Islam Universitas Islam Indonesia \\ Email: yusdani_msi@yahoo.com,Email: imamsamroni@ymail.com
}

\section{Abstract}

Penelitian kualitatif ini untuk menjawab (1) pengetabuan dan tatanilai warga sebelum dan sesudah letusan Merapi 2010; serta (2) konvergensi dan divergensi pengetabuan dan tatanilai warga setelah letusan Merapi 2010.

Penelitian ini merekomendasikan, pertama, dalam hal pengambilan sikap dan tindakan, warga cenderung merujuk sumber informasi dari pemerintah, pengamatan fakta lapangan, dan mempertimbangkan pencerapan pribadi (mimpi atau yang lain). Dibutubkan kajian tentang transformasi sosial dari sejumlah kearifan lokal. Kedua, kebutuban untuk merumuskan posisi dan peran agama dalam kondisi bencana. Dibutubkan pembelajaran agama yang menggugah untuk menjawab permasalahan warga. Ketiga, ketidakoptimalan pemerintab desa untuk melayani kepentingan dan kesejabteraan warga merupakan gambaran dari kebijakan pemerintah tentang otonomi desa. Peranan tersebut tergantikan oleb LSM. Dibutubkan tatakelola penyelesaian pertanian, peternakan, serta sarana dan prasarana umum yang menyangkut hajat hidup warga.

كان هذا الإستقراء العالى إجابا: ا. الفهم و النتيجة للمجتمع قبل او بعد إنفجار

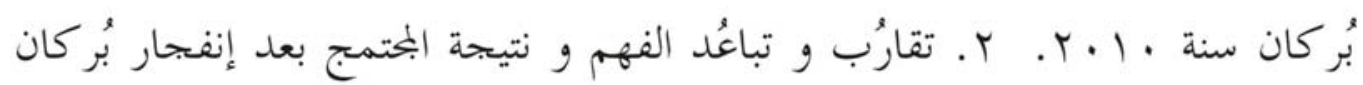

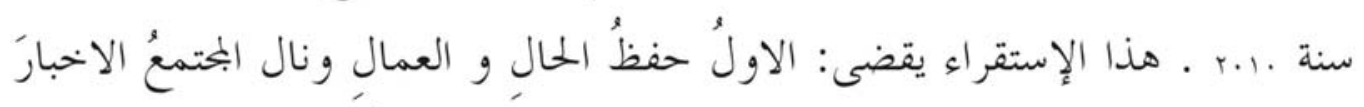
من الحكومة و الإستقراءَّعلى الواقعة و توازنَ النفسي. دراسةُ تحويلِ الإجتماعي من

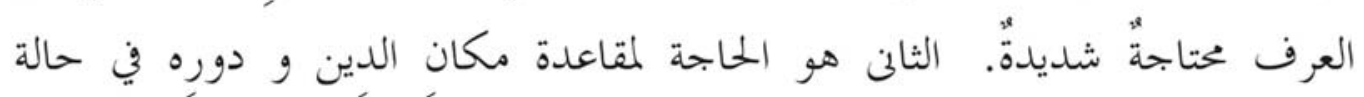

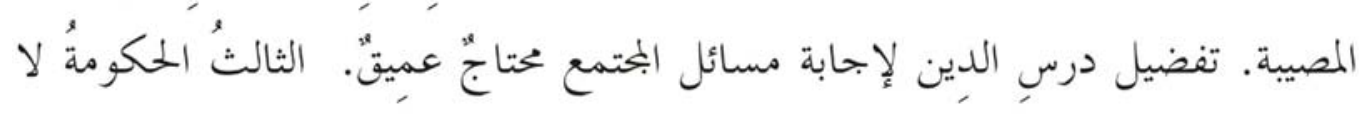




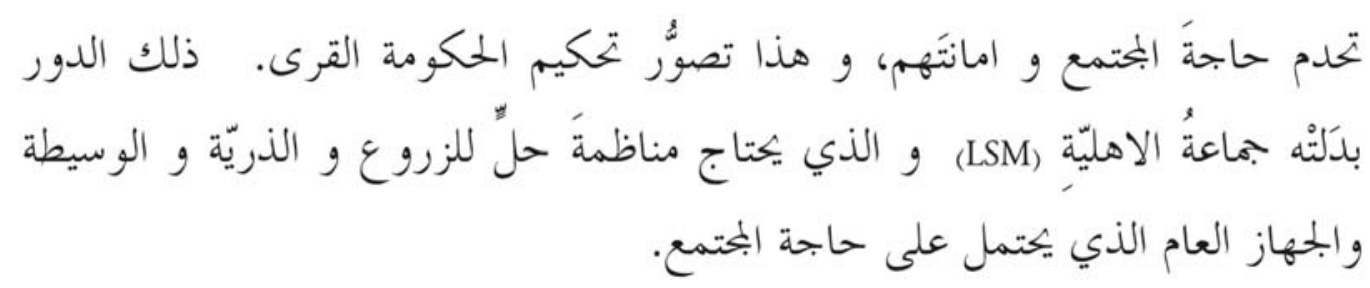

Keywords: convergence, divergence, knowledge, value system and Merapi Mountain.

\section{A. Introduction}

This study took the conditions of Ngandong, Somoitan and Tritis villagers of Girikerto village of Turi subdistrict of Sleman district after the eruption of Merapi in 2010 as its backdrop. News, studies and advocacies of the villagers during the post-eruption period has resulted in the explosion of occurrences as experienced by the villagers. Something about Merapi represented a body of knowledge of "Merapi affairs," which have established in the consciousness of the villagers. Referring to the knowledge-based view and the valuesystem-based expression of the villagers, it studied the pattern of the convergence and the divergence of the knowledge and the value system of the villagers.

The study aimed at answering the two following questions: First, how were the knowledge and the value system of Girikerto villagers of Sleman district before and after the eruption of Merapi in 2010? And, second, how were the convergence and the divergence of the knowledge and the value system of Girikerto villagers of Sleman district after the eruption of Merapi Mountain in 2010? Based on the study questions, its objectives were, first, to gather and to understand the preference of the knowledge and the value system of Girikerto villagers of Sleman district before and after the eruption of Merapi Mountain in 2010 and, second, to analyze the convergence and the divergence of the knowledge and the value system of Girikerto villagers of Sleman district after the eruption of Merapi Mountain in 2010.

The study aimed at, first, gathering and understanding the preference of the knowledge and the value system of Girikerto villagers of Sleman district before and after the eruption of Merapi Mountain in 2010 and, second, analyzing the convergence and the divergence of the knowledge and the value system of Girikerto villagers of Sleman district after the eruption of Merapi Mountain in 2010.

The usefulness of the study represented the responsibility of the authors were to: First, academically elaborate the convergence and the divergence of the knowledge and the value system of Girikerto villagers of Sleman district, especially all matters 
appertaining to disaster and the social mapping of the knowledge and the value system of the villagers and the result was the availability of database to analyze the mitigation policy of the disaster of Merapi Mountain based on the experience of the villagers; and, second, practically make an inventory of "the collection" of the knowledge and the value system of the villagers, especially in mental-spiritual cluster. Therefore, "the collection" of the knowledge and the value system of the villagers could be optimized for the recovery of their condition after the eruption.

The operational definition of the study included, first, Merapi villagers were those living in Nandong, Somoitan and Tritis villages of Girikerto village of Turi subdistrict of Sleman district; second, the knowledge of the villagers was the collection of the knowledge that grew and developed among them. The knowledge of the villagers had its sources in the government authority and daily understanding. It was the layers of the knowledge commonly referred to as local wisdom (Bagus, 2000; 803; Nugroho, 2006; Machrus, 2010; Susanto, 2006); third, the value system of the villagers was the reference that was considered by the villagers and had its source in ethics with the criteria of good and bad, right and wrong, useful and useless; and the knowledge belonged to the heart of the villagers (Gusti, 2010); fourth, the convergence of the knowledge of the villagers was the one of various knowledge sources they apprehended and became the reference of the value system in their daily life in term of their religious impression of the eruption; the experience as villagers-refugees; the presence of the actors or social order; and living arrangement after the eruption (Primiero, 2008: 122-123; Domfeh, 2007; Arismunandar, 2006; Inkeles, 1989: 10-15; Turner, 2006: 90-91; Stallings, 2007: 61-62); and fifth, the divergence of the knowledge and the value system of the villagers was the separation and the non-integration of various sources of the knowledge they apprehend and became the reference of the value system in their daily life in term of the religious impression of the eruption; the experience as villagers-refugees; the presence of actors or the social order; and the life arrangement after the eruption.

\section{B. Study Method}

There were three kinds of categories in the study. The first was Category 3 (C3), which were attitude and action. The second was Category 1 and 2 (C1 and $\mathrm{C} 2$ ), convergence and divergence. And the third was Category 4 (V4), which was "the collection" of the knowledge and the value system of the villagers before, during, and after the eruption of Merapi Mountain. Category 4 was detailed on the 
sequence of the occurrences (before, during and after the eruption) for that its impact on the dependent variable could be observed and conclusion about the correlation between Category 3 and Category 1 and 2 could be drawn. The correlation between the categories was illustrated in the figure 1 below.

Figure 1. The correlation between the categories of the study

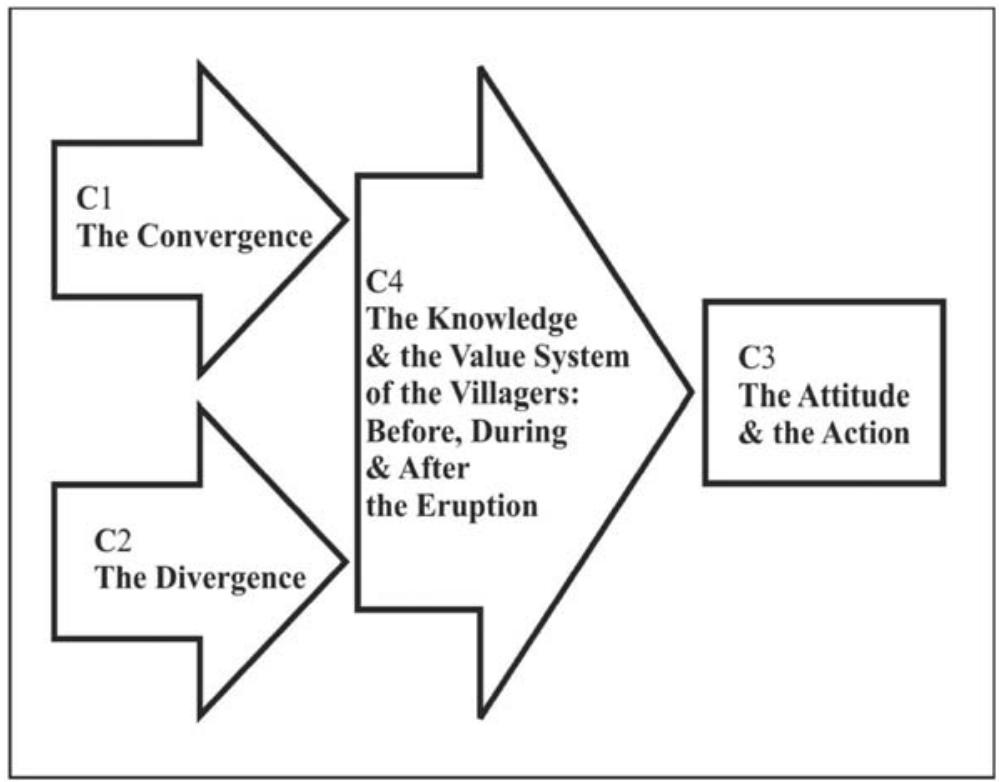

The data of the study were collected using survey, participatory observation, in-depth interview and in-field note taking. Each of the methods was considered to be the same as the main source that was the knowledge and the value system of the villagers as expressed by 15 resource persons from three villages and for the comparison triangulation source.

The survey was conducted by investigating the documents of online media, especially http:/ / kompas.com from April $17^{\text {th }}, 2006$ to December $9^{\text {th }}, 2010$, consisting of 291 bundles. Other media was http://merapi.combine.or.id, http:// portal.vsi.esdm.go.id, http:/ / tikusdarat.net, http://www.mediaindonesia.com, http:/ /sabdalangit.wordpress.com, http://alangalangkumitir.wordpress.com, http:// wongalus.wordpress.com, and other websites. The referred legislation was the Act No. 24 of 2007 on Disaster Tackling.

The participatory observation was conducted to collect the primary data of the knowledge and the value system and hence the authors involved themselves in 
the action taken by the villagers as the subject of the study or the resource persons. During the in-field work, they took a note of important things in an in-field note containing descriptive part and reflective part about the illustration, the condition, and other description of the field (Moelong, 2004; 153-160).

The in-depth interview was conducted in the period of January $3^{\text {rd }}-11^{\text {th }}$, 2011 in two forms, which were structured and unstructured with the recapitulation of the resource persons as presented in the table 1 below. The unstructured interview was conducted to gather non-standard information that usually emphasized exception, deviation and uncommon interpretation (2004: 138-139). The structured interview was conducted to collect comparative data from the resource persons who were expert in explaining the volcano.

Table 1. The recapitulation of villagers-resource persons

\begin{tabular}{|l|l|l|l|l|l|l|l|}
\hline RP & Village & G & A & Religion & Occupation & Time & FN \\
\hline RP 1 & Ngandong & F & 32 & Islam & Farmer & $5-1-2011$ & FN 1 \\
\hline RP 2 & Ngandong & M & 50 & Gerindo & Farmer & $5-1-2011$ & FN 2 \\
\hline RP 3 & Ngandong & M & 27 & Islam & Farmer & $3-1-2011$ & FN 3 \\
\hline RP 4 & Ngandong & M & 70 & Islam & Farmer & $4-1-2011$ & FN 3 \\
\hline RP 5 & Ngandong & M & 45 & Sapta Darma & Farmer & $9-1-2011$ & FN 4 \\
\hline RP 6 & Somoitan & M & 72 & Islam & Farmer & 11-1-2011 & FN 5 \\
\hline RP 7 & Somoitan & M & 26 & Islam & Private Teacher & $7-1-2011$ & FN 6 \\
\hline RP 8 & Somoitan & F & 35 & Islam & Housewife & $11-1-2011$ & FN 7 \\
\hline RP 9 & Somoitan & M & 70 & Islam & Retired Teacher & $9-1-2011$ & FN 8 \\
\hline RP 10 & Somoitan & M & 45 & Islam & Private Employee & $6-1-2011$ & FN 9 \\
\hline RP 11 & Tritis & M & 48 & Islam & Teacher & $6-1-2011$ & FN 10 \\
\hline RP 12 & Tritis & F & 40 & Islam & Merchant & $6-1-2011$ & FN 10 \\
\hline RP 13 & Tritis & M & 37 & Islam & Farmer & $5-1-2011$ & FN 11 \\
\hline RP 14 & Tritis & M & 52 & Islam & Farmer & $5-1-2011$ & FN 12 \\
\hline RP 15 & Tritis & M & 52 & Islam & Farmer & $5-1-2011$ & FN 13 \\
\hline
\end{tabular}

\section{Note:}

RS : Resource person

G : Gender, $M$ (male) and F (female)

A : Age (year)

FN : Field note as enclosed 
The steps in analyzing the data were coding, matrix formulation, occurrence index filling, conceptual net formulation and conclusion test and the triangulation technique with seven resource persons was used to test the conclusion.

\section{The Results}

The following passage discusses the results of the study of the knowledge and the value system of the villagers before, during and after the eruption of Merapi Mountain in 2010 and the results of the triangulation for the convergence and the divergence of the knowledge and the value system of the villagers after the eruption of the volcano in 2010.

The discussion of the knowledge and the value system of the villagers was divided into the stages before, during and after the eruption of the volcano in 2010 as presented in table 2 below. The knowledge and the value system of the villagers before the eruption consisted of the way to obtain social lesson, the process of social learning, actors or social order and the memory of the eruption. The knowledge and the value system of the villagers during the eruption dealt with the rescue of self, family and social environment, the relationship of self with the Creator, and the explosion that marked the eruption of the volcano. Meanwhile, the knowledge and the value system of the villagers dealt more with the religious impression of the eruption of the volcano, the experience as villagers-refugees, the presence of the actors of the social order, and the life arrangement. The analysis of the stage after the eruption dealt with the value system of the villagers during the eruption of the volcano. 
Table 2. The knowledge and the value system of the villagers of Merapi

\begin{tabular}{|c|c|c|}
\hline \multicolumn{3}{|l|}{ Before Eruption } \\
\hline 1. Source & : & $\begin{array}{l}\text { The source of the knowledge of Merapi. It } \\
\text { included the results of the factual and direct } \\
\text { observation of the villagers of the condition of } \\
\text { Merapi; consisting of any fact, any data and any } \\
\text { information about Merapi provided by } \\
\text { government and dream source (i.e., inspiration } \\
\text { (Jv. Wisik), order (Jv. Dhawuh), etc.). }\end{array}$ \\
\hline 2. The method to obtain & $:$ & The method to obtain the knowledge of Merapi. \\
\hline 3. Social learning process & : & $\begin{array}{l}\text { The learning process of the villagers about the } \\
\text { knowledge and the value system of Merapi. }\end{array}$ \\
\hline 4. Actors and social order & : & $\begin{array}{l}\text { The learning process of the villagers along with } \\
\text { the actors and/or the social order about the } \\
\text { knowledge and the value system of Merapi. }\end{array}$ \\
\hline $\begin{array}{l}\text { 5. The memory of the } \\
\text { eruption }\end{array}$ & : & $\begin{array}{l}\text { The memory of th e villagers of the social } \\
\text { learning process about the knowledge and the } \\
\text { value system of the eruption of Merapi before } \\
2010 \text {. }\end{array}$ \\
\hline \multicolumn{3}{|l|}{ During Eruption } \\
\hline 6. Self rescue & : & $\begin{array}{l}\text { The self rescue was done on the knowledge and } \\
\text { the value system as a result of the social learning } \\
\text { process of the villagers. }\end{array}$ \\
\hline 7. Family rescue & : & $\begin{array}{l}\text { The family rescue was done on the knowledge } \\
\text { and the value system as a result of the social } \\
\text { learning process of the villagers. }\end{array}$ \\
\hline $\begin{array}{l}\text { 8. Social environment } \\
\text { rescue }\end{array}$ & : & $\begin{array}{l}\text { The social environment rescue was done on the } \\
\text { knowledge and the value system as a result of the } \\
\text { social learning process of the villagers. }\end{array}$ \\
\hline $\begin{array}{l}\text { 9. The relationship of self } \\
\text { and the Creator }\end{array}$ & : & $\begin{array}{l}\text { The knowledge and the social value about the } \\
\text { position and the relationship of the villagers and } \\
\text { Merapi. }\end{array}$ \\
\hline $\begin{array}{l}\text { 10. The explosion mark } \\
\text { during the eruption }\end{array}$ & : & $\begin{array}{l}\text { The knowledge and the value system referring to } \\
\text { the time when Merapi erupted, consisting of the } \\
\text { inclination of the villagers of the eruption. }\end{array}$ \\
\hline \multicolumn{3}{|l|}{ After Eruption } \\
\hline $\begin{array}{l}\text { 11. The religious } \\
\begin{array}{l}\text { impression of the } \\
\text { eruption }\end{array}\end{array}$ & & $\begin{array}{l}\text { The knowledge and the value system of the } \\
\text { villagers resulted from texts and/or religious } \\
\text { experiences. }\end{array}$ \\
\hline
\end{tabular}




\begin{tabular}{|l|l|l|}
\hline $\begin{array}{l}\text { 12. The experience as } \\
\text { villagers-refugees }\end{array}$ & $:$ & $\begin{array}{l}\text { The knowledge and the value system based on the } \\
\text { experience of the villagers when they left their } \\
\text { homes and became refugees both barrack refugees } \\
\text { and independent refugees. }\end{array}$ \\
\hline $\begin{array}{l}\text { 13. The presence of actors } \\
\text { or social order }\end{array}$ & $:$ & $\begin{array}{l}\text { The knowledge and the value system of the } \\
\text { villagers that were collected because of their } \\
\text { position and relationship with the actors and/or } \\
\text { the social order since they left their homes and } \\
\text { became refugees. }\end{array}$ \\
\hline 14. Life arrangement & $:$ & $\begin{array}{l}\text { The knowledge and the value system of the } \\
\text { villagers as actualized in their relationship with } \\
\text { hope, planning and their action to manage their } \\
\text { daily life after the eruption of Merapi and after } \\
\text { coming back to their respective villages. }\end{array}$ \\
\hline
\end{tabular}

Based on the table above, the knowledge and the value system of the villagers before, during and after the eruption of Merapi are presented below.

First, the source was direct observation of the condition of Merapi and personal apprehension through dreams (Jv.Wisik), order (Jv. Dhawuh), etc.), while the information of the status of the volcano was disseminated by government (BPPTK). The source of the knowledge of the villagers of the status of the volcano was government and supported by direct observation and dreams.

Second, the method to obtain the information was observing and reading media, especially as mediated by television. The conversation of the villagers about the up-to-date news of the television would confirm the information from village head and neighbors. The television presentation was classified into news and infotainment. Additionally, some of the villagers directly observed the latest condition of the volcano and considered observable natural phenomena in addition to the dreams that were personally apprehended.

Third, the family social learning process took place among family members and also the neighbors. In general, the learning process in a society was facilitated by village head and attended by the representative of the villagers. It meant that not all of them were invited and involved in the meeting. The results of the meeting initiative of the villagers were disseminated to all of the villagers. Meanwhile, the learning process to manage the information from their dreams took place in the forum of ritual meal ( $v$. Kenduri), self-supporting patrol ( $v$. Ronda) and other rituals especially organized for that purpose. 
In the social learning process, the function of communication means such as hand phone and handy talky radio has shifted the function of gong (one of Javanese traditional music instruments in gamelan ensemble) and kentongan (drum made from bamboo or wood which is struck to sound an alarm). The mass media, especially television also became social learning means to disseminate and to confirm the information of the progress of the volcano's status.

The clarity of the knowledge source and the method to obtain it should refer to the values that were considered to be good. Based on the in-field observation the learning instrument and the learning environment became one. The learning instrument was all of the functions in the social learning process, while the learning environment was the situation in which the learning instrument did not function. The social learning process involved all of the villagers and took place in their daily life. The daily life social learning process was the one that have not been planned and structured. They have never obtained the education in the matters appertaining to disaster in a programmed and structured manner from the government. It meant that the social learning process of the matters appertaining to the disaster of the eruption of the volcano took place naturally just as they led their daily life.

The knowledge that had its source in the government became the instrument and the media in the social learning process. It was the knowledge that was further disseminated by the mass media, while the knowledge resulted from direct observation and dreams were referred to confirm the truth of the information from the government, which remained to be the basis in their decision making to have certain attitude. The three knowledge sources influenced each other in the social learning process to have certain attitude and to take certain action. The social learning process was also related to the position of village head in the cosmology of Merapi, which was closely related to Ngayogyakarta Palace. Figure 2 illustrated the social learning process. 
Figure 2. The social learning process of Merapi

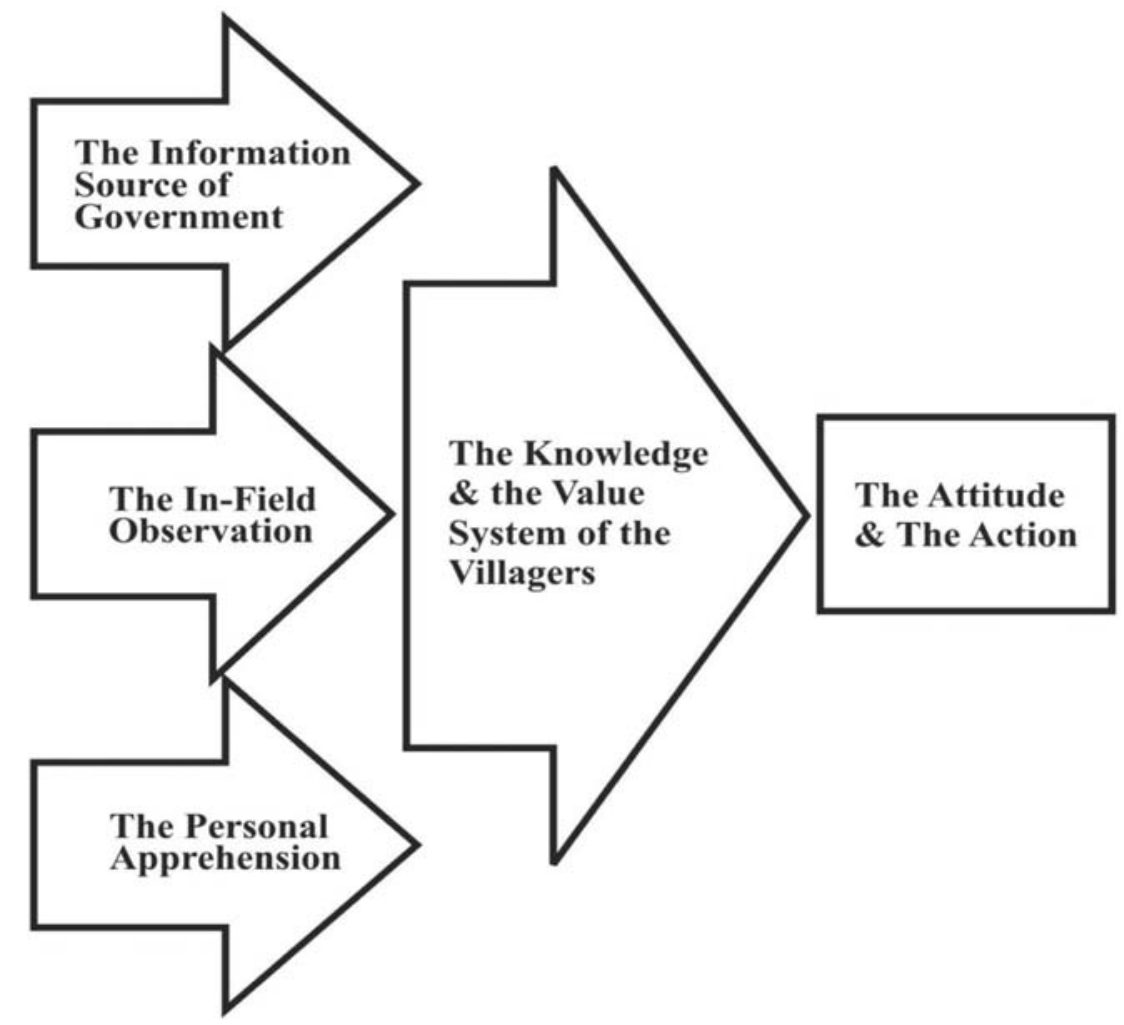

Fourth, the actors or the social order consisted of government and nongovernment. The government was here represented by BPPTK, village government, village head, police, Babinsa, and Tagana. The non-government consisted of $S A R$, religion illumination officers, FPUB, Banser NU, volunteers, and Ngayogyakarta Palace. The actors and the social order were involved in tackling disaster, especially how to rescue the villagers when the eruption of the volcano took place.

Fifth, the memory of the eruption was something very important and different from the memory of the previous years and with significant impact.

Sixth, the rescue of self represented the decision necessary to do by the villagers to save them from the eruption of the volcano.

Seventh, the rescue of family was the action related to the social learning process before the eruption, the availability of structure and infrastructure and also the method to support family and neighbor.

Eighth, the action to save environment was based on the decision to collectively save the life of the villagers. In a critical situation, the rescue became their collective 
interest. The involvement in the rescue took place because of the existing social relationship in the villages. It was believed that disaster repelling rituals ( $V v$. tolakbalak) was able to minimize the risk of the disaster. Such rituals have been organized to strengthen the effort to save social environment since 1961.

Ninth, the relationship of self with the Creator confirmed that the eruption of the volcano represented an important occurrence for all of the villagers. The eruption reminded them of their position and their relationship with Merapi Mountain that has been giving them blessing and life sustenance. The knowledge and the value system was the expression of the villagers in paying respect to life sustainability. In the situation before and during the eruption, they glorified the all powerful Creator with their own expression as Javanese. The relationship was manifested in the act of saying God's names; reading al-Quran; night prayers; group recitation of al-Quran; shalawatan (invocation delivered for the Prophet Muhammad SAW); Islamic optional fasting; sungkem ( $v v$. showing respect by kneeling and pressing o.'s face to another's knees) and silaturahmi (establishing good friendship); and having sincere attitude.

Tenth, the explosion that marked the eruption was considered to be the mark of collective memory of the villagers. The eruption represented a very important occurrence that formed the knowledge and the value system and considered as the test-proof of their belief in the One; the punishment of the One; the reminder of God; the disaster on God's will, learning calamity and economic calamity; and the anger on Merapi's will. All of the government apparatus has left the villages and there remained the volunteers of Tagana and Banser NU.

Eleventh, the religious impression of the eruption confirmed that religion was a direction and a guideline for the villagers in leading their daily life by maintaining the awareness of God's will. Good friendship (silaturabmi) was established for the purpose of harmony life in a union with Merapi. The cleanness of heart should be manifested in verbal expression and social action, being pious to God and alert attitude. The social cohesiveness of the villagers who followed various faiths and beliefs was maintained as the manifestation of the sense of being grateful to God, believing only in God and not mystics, and also the reminder to always be grateful to God as manifested in the daily life in the villages.

Twelfth, the experience as villagers-refugees was considered to be the rescue of self and family by leading a temporary life in refuge barracks, while at the same time taking care of their cattle and livestock to make a living for their families. Being refugees was a collective decision when they left their houses and met in 
evacuating points to depart to the refuge barracks and to manage their daily life as villagers-refugees. The collective decision was the one made collectively by the villagers. It was on the collective decision that they shared their life burden.

There was, however, an annoying problem about the management of the refuge barracks; being blessed with Allah's protection while maintaining their tradition; saving families and being afraid of government; togetherness atmosphere; the situation of homesick; and worrying their cattle and livestock they left in their houses as their important livelihood source during their temporary life in the refuge barracks.

Thirteenth, the presence of the actors of the social order confirmed that being in the position as refugees the villagers still needed the role of government. The non-optimal role of the government caused the shift in the following evaluations of the government:

$\square \quad$ The village government presented itself by visiting the villagers because of the close distance to the location of the refuge barracks. When the government apparatus also became refuge, they did not serve their function as government apparatus;

․ There were vagueness and non-transparency of the government in the distribution of support and assistance;

․ The village government gave the villagers direction to be calm during their temporary life as refugees;

$\square \quad$ The management of the evacuation post of APMD was good;

$\square$ The management of the evacuation post of Pangukan Sport Hall was bad;

ㄱ The government paid more attention to the eruption than that in 2006;

$\square$ There were a logistic management and infrastructure advocacy by non-government organizations;

․ The recitation of al-Quran in the refuge barracks functioned as maintaining the hope of the villagers;

ㄴ There was a need to the religion that awakened the villagers to seek for livelihood.

Fourteenth, the life arrangement included the knowledge and the value system of the villagers as manifested in the relationship with hope, planning and the action to manage their daily life after the eruption with the following findings:

․ The confusion of the villagers who depended on their seriously damaged agriculture and animal breeding efforts. The support of groceries served only as an emergency life rescue and not as daily life support in answering their daily life requirements;

․ Transition condition;

$\square$ The villagers were very optimistic because they understood the behavior of the volcano using "ilmu sanubari" (the knowledge of hearth). Merapi was considered as the source of livelihood and no reason to leave the volcano;

$\square$ Being grateful for the support and assistance of groceries from the village government; 
$\square \quad$ The damaged Zalacca palm plantation resulted in harvesting failure;

$\square \quad$ The villagers made a livelihood based on their area of skills and by sharing information and no need to continuously depend on government, consistently being pious to God, establishing a good relationship with fellowmen and nature, and maintaining humanitarian spirit;

$\square \quad$ They planted trees in slopes of the mountain to restore the damaged agriculture land, plantation and animal breeding;

$\square \quad$ The facilitating activity by FPUB was public lighting and fresh water pipe lines installation to secure the supply of the fresh water for the villagers, which was not accommodated by the government;

$\square \quad$ There was a strong willingness to materialize the ideal of self-sustained and independent villages after the eruption by collective and self-supporting effort for common progress and advancement;

$\square \quad$ The villagers kept maintaining their Zalacca palm plantation and considered to leave their village only if there was no more hope to lead a normal life in their villages and appreciated mutual assistance (gotong-royong) for common safety and security.

Using the knowledge and the value system of the villagers before, during and after the eruption as the point of departure, the study would analyze the convergence and the divergence of the knowledge and the value system. It focused on the analysis of the convergence and the divergence of the knowledge and the value system after the eruption. Therefore, the authors referred to the responses of a number of resource persons about (1) religious impression; (2) villagers-refugees; (3) the actors and the social order in refuge management; and (4) the life arrangement of the villagers after the eruption.

\section{Religious Impression}

The religious impression of the villagers about the eruption of Merapi resulted in a number of responses, which put the relevance of religion in the effort to tackle the disaster of the volcano eruption. It meant that religion surely answer the problems faced by the villagers because of the eruption of the volcano. The religion was meaningful for the villagers in understanding, interpreting, having attitude toward and taking actions before, during and after the eruption.

The religious impression of the resource persons was manifested in their understanding of the functional and transformative powers of the religion that offered the villagers the complete reliance on all powerful God in leading their daily life as religious service to God.

Adib Susila, the founder of Nun-XXV foundation denied the position of the disaster as God's punishment because he considered the volcano as a creature that was performing its bow before its Creator by citing al-Zalzala sura, especially the verses 4-5: 
(4) On the day the Earth announces itself, (5) it is because your God commands the Earth to behave so.

The existence of the volcano that was erupting represented the determination of God and its bow before its Creator and it was the Creator who commanded the eruption. The God's determination of the bow of the volcano has long become the value system of the villagers, especially those living around the volcano. He suggested that:

The sub-cultural power referring to the texts and the local wisdoms of Javanese could be traced in the doctrine of the al-Zalzala sura. The sub-culture also made a clear distinction between the source of knowledge (Jv. kawrub) and the virtue (Jv. ngelmu) and all its consequences. There was a distinction between obtaining and learning knowledge: the "kawrub" was limited only to the information that was produced in a social space, while the ngelmu should be obtained through asceticism and tight self-discipline. The "kawrub" was limited only to the knowledge, while the "ngelmu" was the value system the villagers referred as the basis in having certain attitude and taking certain actions. ${ }^{1}$

Adib Susila appreciated the ability of the preference of the villagers to "mystic religion" in improving their ability to memorize ( $J v$. titen, repetition) and to have a calm attitude. The followers of the "mystic religion" had a better ability to apprehend (iqra) and to manage (tadabbur) of the nature of Merapi. The commandment to apprehend (iqra) included all matters that could be reached, indicated a method and improved scientific capability and the apprehending layers consisted of:

Pronouncing alphabet, reading text and understanding its meaning, reading text with metaphoric expressions that were both implicit and explicit in nature, reading the implicit of the explicit of the text, reading the fact and not the texts (i.e., the phenomena of universe), and reading the fact and not the textual that has taken, is being and will take place. The apprehension (iqra) represented a commandment as contained in the verb qara' , which literally meant "reading". The word iqra' has a basic meaning of "collecting," while it is found in a dictionary to mean: Nataqa, pronouncing, talking; Thala'a, analyzing, publishing; Khamala, containing, carrying, supporting; Jama'a, gathering, collecting; Walada, manifesting, expressing; Alqaa, meeting, observing; Ablagha, delivering, transferring; and Talaa, following, miming. Consequently, the villagers with the "ngelmu" and completely aware of the bow of Merapi become the one endowed with magic power to understand and to take care of the volcano. The value of having the "ngelmu," was practically useful in making a livelihood. ${ }^{2}$

Adib Susila expected that the vocabulary of the local knowledge and wisdom could be discussed in Islamic study of laws appertaining to environment (fiqih lingkungan) for the preservation of the nature and the environment of Merapi. The

At the discussion in Yogyakarta, November 26 $6^{\text {th }}, 2010$.

2 Based on the discussion in Yogyakarta, November $26^{\text {th }}, 2010$. 
discussion at scientific level must have practical orientation, which was how Islam could materialize its potential to be God's mercy for whole universe (rabmatan lil 'alamin) and be able to answer the problems facing human being. The usefulness of the discussion of the Islamic laws must be based on transparency because there was an instance that Islam was considered to be a means to magical practices. For example, how was such scientific discussion able to formulate the implementation of the interpretation of the Prophet' word, "And even when tomorrow is the end of the world and this Earth was crushed, today I plants this date palm seed".

Following definition was suggested for the understanding of the villagers that the eruption of Merapi was a God's learning. Learning was for those who were still alive and had a strong willingness to learn the lesson of the important natural occurrence. It was this learning process of which Kiai Haji Masrur Ahmad, a director of Al-Qodir Boarding School, had an impressive experience.

When an extraordinary condition prevailed, with the presence of thundering sound, I invited all of the students to come into a mosque and to invocation for the Prophet Muhammad SAW for self-composing process. Such psychological condition became the basis in making a decision and in having certain attitude toward Merapi. Additionally, the students could also repel the impact of the thundering sound of Merapi by saying Allah's names.

Also, I found a group of congregation who visited this boarding school and prohibited such invocation, doing the invocation faithfully in the mosque. ${ }^{3}$

Kiai Haji Masrur Ahmad, well-known as Mbah Rur, considered religion as direction for human being. Thus, the religion was able to serve as a guideline for the villagers who were facing a disaster. Mbah Rur practiced his religion in the daily life of the villagers. Long before the volcano erupted in 2010, he invited the villagers surrounding the boarding schools to optimize their social learning process. The social learning process was also organized using a traditional art performance Jathilan with its phenomena of being possessed by spirit. The religious figure suggested that:

When someone was deeply absorbed by certain rhythmic music, he or she would enter his or her sub-consciousness. So, it was not because of role played by the shaman. I myself added an invocation for the Prophet Muhammad SAW (shalawat) to the traditional art performance. In the prior instance it was proven that the shalawat could prepare the students to have a calm attitude toward Merapi.

3 Based on the discussion in Al-Qodir Boarding School, Tanjung, Wukirsari village, Sleman district, December $19^{\text {th }}, 2010$. 
When I decided to remain to stay in the boarding school and did not flee, I just felt that I was responsible for the students. The psychological condition of the students was indicative of those with special requirements. Additionally, because of the alert status of the volcano their parents could not pick them up.

Doing the shalawat was the practical instance how religion presented as a means of the social learning of the villagers amidst the extraordinary condition. ${ }^{4}$

Both Adib Susila and Masrur Ahmad invited us to re-read the meaning of complete defenselessness as the religious expression of the villagers. Such defenselessness represented a final stage once any possible effort has been made. Meaning, the villagers did optimal rescue from the eruption of Merapi. The defenselessness referred to the position of self relative to the all powerful Allah. Thus, it was the defenselessness to the all powerful Creator, while doing any possible effort for the rescue and to continue their daily life. It was their decision and not a religious imaging result.

Agus Utantoro, a media practitioner put the minimum presence of the religious figure in media, especially television in the political context of news reporting of each of the existing media. Public in general knew that the local wisdom was represented by the figure Mbah Maridjan. The old man with his nobility title Raden Ngabehi Surakso Hargo who has been assigned as the door-keeper of Merapi by the king of Yogyakarta Hamengku Buwono IX, was the icon of Merapi as reported by the mass media as overstepping his role beyond the door-keeper of the volcano.

According to Agus Utantoro, the politics of news reporting was likely to consider a person as a figure. It was difficult for the media to accept the presence of the other figures in the same area. He said,

"I think, the common sense and the mood of average editorial staffs only accept Simbah Maridjan and tend to deny others. It is all about the politics of news reporting along with its consequences when they cover news in field. Merapi and the old man named Mbah Maridjan have become a complex fact with the risk of biased news reporting. And, in an emergency situation, especially in the daily conversation of the villagers about the television news reporting, the conversation was further biased.

... I am also in a doubt if the news of the local wisdom or those based on religious perspective with the resource persons other than Mbah Maridjan, are acceptable for the editorial staffs. Because of the existing competition among the media, they race to report the news about the old man.

Lets take a closer look at the fact when the first eruption of Merapi on October $26^{\text {th }}, 2010$. My data was indicative of the occurrence of the eruption at 18.10, 18.15 and 18.25. The

4 Based on the discussion in Al-Qodir Boarding School, December 19 ${ }^{\text {th }}, 2010$. 
victims of the eruption were 12 dead individuals, including the old man. All of the media raced to report the news by ignoring and even blurring the fact of the time of the eruption, where was the position of the old man, and the response or the interpretation of the position of the dead old man. ${ }^{5}$

The figure Mbah Maridjan who was compared by the media to Poniman and Mbah Rono (Surono, the Head of the Center for Vulcanology and Geological Disaster Mitigation $[P V M B G]$ of the Geological Body) has become a stage to win certain interpretation among the media. When the old man was died, they raised the figure Poniman. The condition encouraged Nurhadi Sucahyo to discuss it in the social networking website Facebook. He asked the following questions:

․ We ought to make a simple analysis whether Ponimin's house became a maximal shelter against the excessively high temperature cloud when it came. Meaning, was the construction of the house better?

$\square$ Was the high temperature cloud hitting Ponimin's house as catastrophic as the one hitting Mbah Maridjan's house. It was highly possible that the cloud hitting Ponimin's house was not as catastrophic as the one hitting Mbah Maridjan's house.

$\square \quad$ The fact that Ponimin's care still functioned well and moved 3 meters. Meaning, the cable circuitry of the care was normal though it was prone to short-circuiting when it was hit by the excessively hot cloud. Also, the tire rubber of the car still enabled it to move some distance, which indicative of the fact that the tires were not damaged by the hot cloud. It was necessary to investigate it.

$\square$ Ponimin and his family were helped by Mr. Aris, his neighbor who survived the cloud. Meaning, Mr. Aris should have a magic power because he survived the cloud and even could help Ponimin and his family. Is that right? Or, did I falsely hear. If Mr. Aris survived the cloud, he ought to have the same value to report in the news reporting as Ponimin who survived the hot cloud. Why was the story of Mr. Aris not exposed in the news reporting?

$\square \quad$ Was that normal for spirits to bargain something? According to the story told by Ponimin's wife, the old man visiting the village said that he would destroy Keraton Palace, but she manage to prevent him from doing the harm and suddenly the old man said that it was enough for him to destroy Kinahrejo village. Was that possible that the damage was bargained in such a way. Remember, destroying Keraton Palace from Merapi with the technology of "hot cloud" ("wedhus gembel") meant destroying the area stretching from Kinahrejo village to Keraton Palace Yard and it required more than $30 \mathrm{~km}$ hot cloud and would surely take a big number of lives.

- It was said that the spiritual creature would do the harm using fire, storm, ground and water. It would be like the Avatar in Nickelodeon movie. No comment.

5 Based on the discussion in Sleman, January 14 ${ }^{\text {th }}, 2011$. 
․ It was also necessary for us to re-check that in 2006 Ponimin has resigned from the position as the servant of the king of Yogyakarta (Abdi Dalem) because of the case that he was not included in the advertisement with Mbah Maridjan as the star. It meant that his status was deserter. Was that logic for a deserter to get promotion? It did not reflect the personality of the servant of the king of Yogyakarta that he was angry because he was excluded from the production of the "rosa-rosa" advertisement. Was that proper for a servant of the king of Yogyakarta to have such personality?

Being a figure resulted in elite risks, bias and ignoring the breadth of the religious impression of the villagers of the eruption of Merapi. It had also the consequence of ignoring the highly diversified news reporting about the functional and transformative powers of religion to awaken the villagers about the all powerful God in their daily life practices.

The religious impression of the villagers confirmed that Merapi was not a sheer metaphysical entity. The impression showed the dialogue and the grappling of the villagers with their religion in the daily time and space dimensions. It detailed the empirical evidences of the eruption of the volcano, formulated a conceptualtheoretic definition of the social meaning of the volcano, and even the meaning of its presence in the inner space of the villagers. The eruption of the volcano has really been a discursive eruption confirming the need of the villagers for a religion that had functional and transformative powers to answer their need for social benefits (maslahat).

Thus, the religious impression has driven the divergence of the knowledge and the value system of the villagers about how to make a living after the eruption.

\section{Villagers-Refugees}

The villagers-refugees were deeply appreciated as humanitarian problem. The appreciation was not merely related to the disappointment of the management of the refuge barracks; being blessed with Allah's protection while maintaining their tradition; saving families and being afraid of government; togetherness atmosphere; the situation of homesick; and worrying their cattle and livestock they left in their houses as their important livelihood source during their temporary life in the refuge barracks, but in the humanitarian context of the refugees.

6 The response of "Ponimin, Surono, dan ini itu," in Nurhadi Sucahyo's Facebook, responded by the author on October $29^{\text {th }}, 2010$ has been a lively discussion, especially among journalists. 
AB. Widyanta, an activist of Kaldera Institute, advocated the refugees in the network of independent evacuation post in Kadisoka, confirmed the aforementioned statement of Girikerto villagers. Indeed, the eruption of the volcano has caused the emergence of the ethics of togetherness in facing and minimizing risks, but the criteria of the management of the refugees was of the kind of humanitarian one. Based on the comparison of the humanitarian works during the earthquake of Jogja-Central Java on May 27 $7^{\text {th }}, 2006$ and the eruption of Merapi on October $26^{\text {th }}, 2010$, AB. Widyanto formulated five actors with their respective roles as follows:

First, the "new celebrity" figure Surono, the Head of PVMBG who played many important roles in the mitigation of the eruption of Merapi. Second, SAR team with its deadly struggle. Third, hospital medical teams that provided the wounded and dead victims with skilled medical services. Fourth, the academic circles of universities, which were highly responsive to and capable to ease the burden of the refugees and to answer their basic needs. Fifth, the network of civil society that accepted the refugees in independent evacuation posts in Yogyakarta and Central Java on self-supporting basis. The world would record the history that there would be no evacuation posts as sincerely, friendly and integrated as found during the eruption of Merapi.

AB. Widyanta suggested zero victims and zero accident principle and the agreement of the post-eruption management. Therefore, it was necessary to organize a dialogue that involved the villagers. The existing reports on the refuges confirmed the presence of strong and rich civil society with its social capital necessary to promote reliable disaster governance. The reports also proved that the independent evacuation posts represented an alternative model of refugee management that must be developed in tackling disasters in the future.

Thus, the statement of the villagers-refugees has caused the convergence of the knowledge and the value system about the local wisdom of social capital and the sense of togetherness.

\section{Actors and Social Order in Refuge Management}

Being in the position of refugees, most of the resource persons still required the role of government. The non-optimal role of the government caused evaluation shift and even the shift to governance. Concerning with the non-optimal role of the village government, it was false according to Prof. Susetiawan, a sociologist of Gadjah Mada University. 
Village referred to the territory in which the villagers lived with production sources and governance and operated under rules of the game agreed by the villagers, the rules of the game in enforcing the rules of government. From the point of view of Indonesian history, the existence of villages preceded the existence of state. Therefore, since the beginning the villages represented autonomous entities. ... Over time they were transformed into the parts of the central government and marginalized into periphery and lost their autonomy. ${ }^{8}$

According to Susetiawan who was also the activist of Komite Kemanusiaan Yogyakarta $(K K Y)$, the statement of the villagers that the villages have shown the politics of attention by visiting them in the refuge barracks and it was good thing. Based on their main task and function and considering the limitation in financing, the village apparatus were not designed by the central government to totally tackle the disaster. The more important thing was the coordination with other institutions in accordance with their roles and functions. It was in this context that visiting the refugees provided them with social support.

Susetiawan also observed the strong determination of the interests of industrial countries that have broaden and are broadening the market of their industrial products. The national-village integration strengthened the global space for the interest of industrial marketing. The capacity of the villages to develop, to be sovereign and capable of warranting the prosperity of the villagers after the eruption of Merapi was all the conditions that could not imagined on the existing act on village government.

Based on the above analysis, Susetiawan suggested the definition of local wisdom. There was a statement among the villagers that the change of the natural environment caused by the catastrophic eruption of Merapi resulted in the change of the local knowledge.

Since the government has implemented the policy to evacuate the cattle and the livestock of the villagers, there was no need for them to take care of the cattle and the livestock. They came back to their village to provide them with green fodders. The cattle became the source of their livelihood and the source of economic living of the villagers. Of course, they consider their safety at the first place when they were in their village in case of new eruption. They were also alert of the status of Merapi. However, it was the only choice for them to survive. Crops and plantation have been damaged and no other choice for work. They were not productive in the refuge barracks and they did not get any financial income, while the support of basic groceries served only the function to survive until the time they did not know in addition to the damaged public structure and infrastructure.

8 At the discussion in Sleman, March $3^{\text {rd }}, 2010$. 
So, coming back to their villages in the morning and back to the barrack in the evening was the matter of making livelihood. It was not local wisdom. It was necessary for us to further analyze it. If the policy to evacuate the cattle and the livestock has been implemented, how we would construct local knowledge??

Thus, the actors or the social order in the refuge management has caused the divergence of the knowledge and the value system about the capacity of the village government in the global context.

\section{The Life Arrangement of the Villagers after the Eruption}

The life arrangement of the villagers after the eruption included the knowledge and the value system as manifested in the relationship with hope, planning and the management of their daily life after the eruption. People in general knew that the eruption of Merapi has caused unprecedented impact, not only ecologically but also psychologically and especially social-economically. The most clearly observed ecological impact was millions hectares of agricultural lands and plantations around the mountain that have been damaged because of excessive volcanic ashes. Crops were dried, trees did not produce fruits, and harvest season surely failed. Public facilities and the physical possessions of the villagers were also damaged. The psychological impact was found among those who were directly hit by the disaster, which were trauma and constant anxiety in addition to the fact that many of their family members became the victims of the eruption. They were wounded, handicapped, and even died.

According to M. Latif Fauzi, the teaching staff of STAIN Surakarta, the refugees coming from Sleman district:

At the same time, they had to think about the recovery of the social and economic condition that was much more important because it related to the continuation of their life. The reality was that most of the livelihood of the villagers of Merapi depended on the fertility of the agricultural land that was damaged by the eruption. Consequently, the economic activity was almost totally collapsed and the life got stuck.

A number of microfinance institutions in Ngemplak and Cangkringan subdistricts were also complaining about the stuck credit because the villagers were not able to pay the installment payment. The "blessing" of construction materials of sand in Opak and Gendol rivers could not be arbitrarily enjoyed by the villagers. The fact was that it was the strong capitalists that could enjoy the blessing. Hundreds of backhoes and other heavy equipments such as crane backhoes were used to exploit the construction materials using the alibi of emergency response. ${ }^{10}$

$9 \quad$ At the discussion in Sleman, March $3^{\text {rd }}, 2011$.

10 At the discussion in Sleman, March 1 ${ }^{\text {st }}, 2011$. 
In such complicated condition, the villagers did not have any other choice. Life must go on. Religious approach to the recovery of the trauma were proven to be cliché and artificial. The social capital (mutual assistance and self-supporting works) was not always reliable. All they needed was practical and productive life arrangement schema. Temporary shelters have been available for those who have lost their houses. Recently, they required proper jobs. The limited cultural potential of the villagers must be structurally considered. The government must really present. The support and assistance schema must be clear. The bureaucratic line must be shortened and simplified. The optimizing of the village government could therefore be the right choice.

However, the life arrangement has caused the convergence of the knowledge and the value system of the villagers about how to make livelihood as the most honest economic claim of their economic life.

\section{Conclusion}

Based on the results of the study and the discussion of the prior chapter, the following conclusions were drawn:

1. Concerning with the knowledge and the value system of Girikerto villagers of Sleman district before and after the eruption of Merapi in 2010:

The information source of the status of Merapi referred to government. The management of the information dissemination to the villagers was not optimal. The emergency response condition justified "situation laws," which was without any sufficient control groups, including the procedure of loss indemnification. There was uneven distribution of the resources in informing the religion that awaken the villagers after the eruption. They required a religion that played common role in finding solutions of the problems facing the villagers in their daily life. There was a shift from "government" to "governance". The apparatus did not present when the volcano erupted. The village government did not function optimally after the eruption. With the limitation of financial resources they organized "the politics of attention" by visiting them in the refuge barracks. The main information about the management of the support and assistance and the up-to-date progress of the status of Merapi was provided by volunteers and non-government organizations.

2. Concerning with the convergence and the divergence of the knowledge and the value system of Girikerto villagers of Sleman district after the eruption of Merapi in 2010: 
There were the convergence of the knowledge and the value system of the villagers in the statement of the villagers-refugees and the life arrangement. Meanwhile, the divergence of the knowledge and the value system took place to the religious impression of the actors or the social order in the refuge management.

\section{Recommendation}

Based on the aforementioned conclusions, the following recommendations were suggested:

1. Concerning with the attitude and action, especially before and during the eruption of Merapi, the villagers were likely to refer to the information source of government, to directly observe Merapi in field, and to consider personal apprehension. The personal apprehension referred here to dreams (or others). Meaning, the convergence of the knowledge and the value system dominated by technology did not completely take place. Considering the knowledge management, the attitude and the action of the villagers remained to refer to the structured knowledge sources. It required a study of the social transformation of a number of social wisdoms as taking place in the rituals organized by the villagers. A number of resource persons confirmed that the local wisdoms must also change because of the change in the natural environment caused by the eruption of the volcano in 2010.

2. The requirement to formulate the position and the role of religion in disaster condition related to the social learning capacity of normatively better future with the synergy between the villagers, the government and other stakeholders. Meaning, the awakening position of a religion was more necessary in finding the solutions of the problems facing the villagers.

3. The non-optimal village government in fulfilling the interests and in warranting the prosperity of the villagers illustrated the policy of the government on village autonomy. In addition to the role in providing information about the status of Merapi, the villagers also questioned other roles, especially the management after the eruption. According to their experience, the roles were taken over by non-government organizations. The problems related to the life of the villagers must be solved by the government and they included agriculture, farming and animal breeding and public structure and infrastructure. 


\section{REFERENCE}

Anonymous, 2006, Mitos Kekuasaan dan Pertanda Alam. Gatra Number 32. Anonymous, 2008, Kamus Bahasa Indonesia. Jakarta, Pusat Bahasa Departemen Pendidikan Nasional.

Anonymous, 2009. Indigenous Knowledge Disaster Risk Reduction: Policy Note. European Union, ISDR, Kyoto University, SEEDS

Anonymous, 2010, Boyolali Aman: Antara Mitos dan Nalar Logis, accessed on November $24^{\text {th }}, 2010$ from http://merapi.combine.or.id/baca/10881/ boyolali-aman $\% 3 \mathrm{~A}$-antara-mitos-dan-nalar-logis.html

Anonymous, 2010, Heru Nugroho: Jangan Paksa Merapi Ikuti Kemauan Kita, accessed on November 24 $4^{\text {th }}, 2010$ from http://suaramerdeka.com/v1/ index.php/read/layar/2010/11/07/696/Jangan-Paksa-Merapi-Ikuti-

Anonymous, 2010, Memperkuat "Jembatan" Maridjan-Surono. Kompas, Desember $20^{\text {th }}$.

Anonymous, 2010, Misteri di Balik Merapi, accessed on November 24 ${ }^{\text {th }}, 2010$ from http:/ / sabdalangit.wordpress.com/2010/11/04/misteri-di-balik-merapi/

Anonymous, 2010, Perhitungan jarak, accessed on November $24^{\text {th }}, 2010$ from http:/ / students.ukdw.ac.id/ 22074214/hitungjarak.php.

Anonymous, 2010, Prof Heru Nugroho: Mitos Merapi Sengaja Dipelihara, accessed on November 24 $4^{\text {th }}, 2010$ from http://www.detiknews.com/read/2010/11/ 02/124552/1482554/158/prof-heru-nugroho-mitos-merapi-sengajadipelihara?nd 991107158

Anonymous, 2010, Prof Heru: Juru Kunci Merapi Tak Penting, yang Penting Warga Terayomi, accessed on November $24^{\text {th }}, 2010$ from http:// www.detiknews.com/read/2010/10/27/174836/1476871/158/prof-heru-jurukunci-merapi-tak-penting-yang-penting-warga-terayomi?nd992203605

Anonymous, 2010, Refleksi Merapi: Siap Rasional, Siap Mental, accessed on November 24 $4^{\text {th }}, 2010$ from http:/ / www.antaranews.com/print/1290389698 Anonymous, 2010, Signal Aktivitas Merapi: Kearifan Lokal Warga Merapi Jadi Pedoman. Suara Merdeka, Nopember $23^{\text {rd }}$. 
Anonymous, 2011, Girikerto, accessed on November 24 $4^{\text {th }}, 2010$ from http:// wapedia.mobi/id/Girikerto.

Arismunadar, Satrio, 2010, Konvergensi Media, accessed on November 24 $4^{\text {th }}, 2010$ from http://satrioarismunandar6.blogspot.com/2006/10/konvergensi-media.html

Baedhawi, M., 2008. Kearifan Lokal Kosmologi Kejawen: Studi Post Kolonial Pandangan Kosmologi Romo Yoso dan Implikasinya Bagi Warga Tutup Ngisor Magelang. In Abdullah, Irwan \& Mujib, Ibnu (eds), Agama dan Kearifan Lokal dalam Tantangan Global (pp. 1-47). Yogyakarta: Pustaka Pelajar.

Bagus, Lorens, 2000, Kamus Filsafat, Jakarta: Gramedia Pustaka Utama.

Bryant, Clifton D. (ed.), (2007). 21st Century Sociology: A Reference Handbook. California: Sage Publications, Inc.

Cofta, Piotr, 2007, Trust, Complexity and Control: Confidence in a Convergent World, England: John Wiley \& Sons Ltd.

Domfeh, K. A 2007), Indigenous Knowledge Systems and the Need for Policy and Institutional Reforms. Tribes and Tribals, Special Volume No. 1, 41-52.

Fritz, C.E., \& Mathewson, J.H., 1957. Convergence Behavior in Disasters: A Problem in Social Control. Washington DC: National Academy of Sciences, National Research Council.

Ghozali, I., 2008. Paguyuban Sabuk Gunung Merapi: Kebijakan Lokal Manajemen Bencana: Pola Penanganan Darurat Letusan Gunung Merapi. In Abdullah, Irwan \& Mujib, Ibnu (eds), Agama dan Kearifan Lokal dalam Tantangan Global (pp. 103-131). Yogyakarta: Pustaka Pelajar.

Gusti, Otto, 2010, Etos Global dan Dialog Peradaban. Kompas, Februari 27 ${ }^{\text {th }}$.

Hildreth, Paul M. \& Kimble, Chris 2002). The Duality of Knowledge. Information Research, Vol. 8 No. 1, October.

Inkeles, Alex, 1989. Konvergensi dan Divergensi dalam Masyarakat Industri. In Attir, Mustafa O. (Ed), Sosiologi Modernisasi: Telaah Kritis tentang Teori, Riset dan Realitas (pp.) Yogyakarta: Tiara Wacana Yogya.

Machrus, 2010, Makna Mitos dalam Kekuasaan Raja-Raja Mataram Islam, accessed on November 24 ${ }^{\text {th }}, 2010$ from http:/ / budayanusantara.blogsome.com/2010/ 11/13/makna-mitos-dalam-kekuasaan-raja-raja-mataram-islam/ 
Miles, Matthew B. dan Huberman, A.Michael, 1992. Analisis Data Kualitatif, Tjetjep Rohendi Rohidi (terj.), Jakarta: UI Press.

Moelong, Lexy J., 2004. Metodologi Penelitian Kualitatif, $18^{\text {th }}$ print, Bandung: Remaja Rosdakarya.

Noeng Muhadjir, 1989). Antisipasi Pengembangan LPTK untuk Masa Depan. Cakrawala Pendidikan, No. 2 of the Year VIII (Dies Natalis XXV Edition). 